\title{
THE POLAROGRAPHIC REDUCTION OF Bi(III) IN THE PRESENCE OF CHLORIDE ION*
}

\author{
H. H. Bauer $\dagger$ and P. J. Elving \\ Department of Chemistry, University of Michigan, Ann Arbor, Michigan, U.S.A.
}

\begin{abstract}
The reduction of $\mathrm{Bi}(\mathrm{III})$ to $\mathrm{Bi}(\mathrm{Hg})$ at the dropping mercury electrode in $0.5 \mathrm{M}$ perchloric acid solution containing $0-0.3 \mathrm{M}$ chloride ion becomes increasingly reversible, generally speaking, as the $\left[\mathrm{Cl}^{-}\right] /[\mathrm{Bi}(\mathrm{III})]$ ratio increases, as evidenced by changes in various criteria used for determining the "reversibility" of a polarographic electrode process, e.g., the magnitude of the heterogeneous rate constant of the electrochemical reaction $\left(k_{s}\right)$, the slope of the d.c. polarogram log plot, and the magnitude of $\rho$, the a.c. polarographic efficiency (ratio of the observed and theoretical magnitudes of the faradaic alternating current). The concentration ratio is not, however, the sole determining factor; the absolute concentrations also have an effect. The log plot is apparently a quite inadequate measure of reversibility; $k_{e}$, which is a determining factor in the d.c. polarographic reversibility, is probably not functionally related to the thermodynamic reversibility of the electrode process; $\rho$ could be a measure of the thermodynamic reversibility of the electrochemical process.
\end{abstract}

Résumé--La réduction polarographique de $\mathrm{Bi}(\mathrm{III})$ à $\mathrm{Bi}(\mathrm{Hg})$ dans une solution $0,5 \mathrm{~m}$ d'acide perchlorique contenant $0-0,3 \mathrm{~m}$ d'ion chlorure devient généralement de plus en plus réversible avec l'augmentation du taux $\left[\mathrm{Cl}^{-}\right] /[\mathrm{Bi}(\mathrm{III})]$. Ceci est démontré par divers critères utilisés pour indiquer la réversibilité de processus polarographiques, par exemple la grandeur de la constante de masse hétérogène pour la réaction électrochimique $\left(k_{e}\right)$, la pente du diagramme $\log \left[\left(i_{d}-i\right) / i\right]-E$ ainsi que la grandeur $\rho$, le "rendement" en polarographie à courant alternatif, c'est-à-dire le quotient entre le courant faradaique observé et le courant mesuré. Le taux $\left[\mathrm{Cl}^{-}\right] /[\mathrm{Bi}(\mathrm{III})]$ n'est cependent pas le seul facteur déterminant la réversibilité du système; les concentrations absolues sont également importantes. Il semble que la pente logarithmique soit un critère insuffisant pour la réversibilité; le facteur $k_{e}$, déterminant en polarographie à courant continu ne dépend probablement pas fonctionellement de la réversibilité thermodynamique du processus à l'électrode; $\rho$ par contre pourrait être une mesure de la réversibilité thermodynamique du processus électrochimique.

Zusammenfassung-Die Reduktion von $\mathrm{Bi}(\mathrm{III}) \mathrm{zu} \mathrm{Bi}(\mathrm{Hg})$ an der Quecksilber-Tropf-Elektrode in $0,5 \mathrm{~m}$ Perchlorsäure mit Zusat $z$ von $0-0,3 \mathrm{~m}$ Chlorid wird bei wachsendem Verhältnis [ $\left.\mathrm{Cl}^{-}\right] /[\mathrm{Bi}(\mathrm{III})]$ im allgemeinen zunehmend reversibler, wobei für die Bestimmung der "Reversibilität" eines polarographischen Prozesses mehrere Kriterien in Betracht gezogen werden, wie z.B. die Grösse der heterogenen Massenwirkungskonstanten für die elektrochemische Reaktion $\left(k_{e}\right)$, die Kurvensteigung im Diagramm $\log \left[\left(i_{d}-i\right) / i\right]$ gegen $E$, sowie die Grösse von $\rho$, der "Ausbeute" in der Wechselstrompolarographie, d.h. das Verhältnis der beebachteten zur theoretischen Grösse des Faraday'schen Wechselstromes. Das Konzentrationsverhältnis $\left[\mathrm{Cl}^{-}\right] /[\mathrm{Bi}(\mathrm{III})]$ ist jedoch nicht der einzige, die Reversibilität des Systems bestimmende Faktor, auch die absoluten Konzentrationen sind massgebend. Die Grösse der Steigung im logarithmierten Polarogramm ist ein augenscheinlich ungenügendes Kriterium fürdie Reversibilität; die Massenwirkungskonstante $k_{e}$, ein massgeblicher Faktor bei der Gleichstrompolarographie, hängt wahrscheinlich nicht funktionell mit der thermodynamischen Reversibilität des Elektrodenprozesses zusammen; $\rho$ könnte hingegen ein Mass für die thermodynamische Reversibilität eines elektrochemischen Vorganges sein.

CURRENT usage of the term "reversibility" in electrochemical literature is generally confusing. Criteria of reversibility are used which depend not only on the system studied but also on the method of investigation, so that a particular system classified

* Manuscript received 30 July 1959.

† Present address: Department of Agriculture, University of Sydney, Sydney, Australia. 
as "reversible" on the basis of one type of investigation may not behave "reversibly" when studied by a different technique. In particular, "reversibility" has been used in several different senses when applied to polarographically observed oxidationreduction systems; this has been particularly so in recent years, when the use of new techniques has provided more and different criteria of polarographic reversibility.

The purpose of the present investigation was to measure several of the parameters regarded as criteria of reversibility, for a system whose apparent degree of reversibility in respect to these criteria could be readily altered by relatively nominal variation of the experimental solution environment. The system chosen was the reduction of $\mathrm{Bi}(\mathrm{III})$ to $\mathrm{Bi}(\mathrm{Hg})$ in $0.5 \mathrm{M}$ perchloric acid which is irreversible, but becomes increasingly reversible in the presence of increasing halide ion concentration. This system is chemically complex and its irreversibility cannot be ascribed to a specific cause; however, since criteria of reversibility are proposed for all types of systems, this is not a deterrent, especially in view of the ease which the observed behaviour of the system can be changed.

\section{BEHAVIOUR OF THE Bi(III) SYSTEM}

Criteria* of reversibility and electrode reaction parameters readily measured by conventional d.c. polarography (log-plot slope, $E_{1 / 2}$ ) and by a.c. polarography $\left(\alpha, k_{e}, E_{s}, \rho\right)$ have been determined for the $\mathrm{Bi}(\mathrm{III})$ reduction over ranges of $\mathrm{Bi}(\mathrm{III})$ and $\mathrm{Cl}^{-}$concentrations (Tables 1 and 2). Relative concentrations of the individual chloro-aquo-bismuth ions present (Table 3) were calculated from the equilibrium constants for the bismuth-chloride system. ${ }^{1}$ The hydrogen-ion activity $\left[0.5 \mathrm{M} \mathrm{HClO}_{4}\right]$ was sufficient to minimize the effect of oxo-bismuth species.

Attempts to treat measured values of the various parameters as averages of fixed values for each of the complex bismuth species (weighted on basis of the percentage compositions, Table 3) did not lead to self-consistent results. This is not surprising, since such attempts could not take into account the rates of interconversion of the species, which are almost certainly an important factor at the interface.

\section{Potentiometric and polarographic potentials}

One criterion of d.c. polarographic reversibility is coincidence of $E_{1 / 2}$ with the potentiometrically measured equilibrium potential. Comparison of the present data on the variation of $E_{1 / 2}$ for the $\mathrm{Bi}(\mathrm{III})$ reduction wave with increasing chloride ion concentration and potentiometric data obtained with the bismuth(III)-bismuth amalgam system ${ }^{2}$ shows comparable potential shifts for analogous chloride levels (Table 4).

\section{Half-wave and summit potentials}

With increasing chloride ion concentration, $E_{1 / 2}$ and $E_{3}$ become increasingly more negative; $E_{1 / 2}$ approximates $E_{s}$ except in the complete absence of chloride, when the d.c. polarographic wave shows an over-potential of ca. $40 \mathrm{mV}$ relative to $E_{g}$. This may indicate that $E_{g}$ is more closely related to the reversible potential of the system than to $E_{1 / 2}$. Supporting this is the fact that the faradaic admittance for

* The items measured include the half-wave potential $\left(E_{1 / 2}\right)$, the slope of the plot of $\log \left[\left(i_{d}-i\right) / i\right]$ vs. $E$, the transfer coefficient $(\alpha)$, the heterogeneous rate constant of the electrochemical process $\left(k_{e}\right)$, the summit potential of the alternating current (a.c.) polarographic wave $\left(E_{z}\right)$ and the efficiency of the a.c. process $(\rho)$. 
Table 1.-Characteristic electrode parametres at bismuth CONCENTRation of $2.53 \times 10^{-4} \mathrm{M}$

\begin{tabular}{|c|c|c|c|c|c|c|}
\hline & \multicolumn{6}{|c|}{ Total chloride concentration $\times 10^{3} \mathrm{M}$} \\
\hline & 0.0 & $2 \cdot 2$ & $6 \cdot 2$ & 18 & 60 & $180^{*}$ \\
\hline$E_{1 / 3} \dagger^{-}$ & -0.441 & -0.410 & -0.413 & -0.415 & -0.444 & -0.474 \\
\hline$E_{8}^{\dagger}$ & -0.401 & $-0 \cdot 410$ & -0.410 & -0.430 & -0.453 & -0.493 \\
\hline Log plot, mV & 40 & 23 & 23 & 23 & 21 & 20 \\
\hline & $\ddagger$ & 0.46 & 0.46 & 0.54 & 0.67 & 0.69 \\
\hline & 0.06 & 0.20 & 0.38 & 0.64 & 1.06 & $(0.98)^{*}$ \\
\hline$k_{e}, \mathrm{~cm} . \mathrm{sec}^{-1}$ & 0.023 & 0.030 & 0.079 & 0.21 & 0.20 & 0.20 \\
\hline
\end{tabular}

* Average values obtained with solutions $\mathrm{e}, \mathrm{j}$ and $\mathrm{k}$ of Table 3 ; all values were reproducible within a few per cent except $\rho$, where the individual values were $1.35,0.68,0.90$.

$\dagger$ Volts vs. saturated mercurous sulphate half-cell.

$\ddagger$ Could not be measured with the present technique.

TABLE 2.-ChARACTERISTIC ELECTRODE PARAMETERS AT TOTAL CHLORIDE CONCENTRATION OF $0.3 \mathrm{M}$.

\begin{tabular}{l|c|c|c}
\hline \multicolumn{3}{c}{ Bismuth concentration, $10^{4} \mathrm{M}$} \\
\hline & 1.25 & 5.1 & $9 \cdot 2$ \\
& & & \\
\hline & & & \\
$E_{1 / 2}{ }^{*}$ & -0.487 & -0.490 & -0.490 \\
$E_{s}^{*}$ & -0.511 & -0.508 & -0.506 \\
$\log ^{*} \mathrm{glot}, \mathrm{mV}$ & 20 & 19 & 20 \\
$\alpha$ & 0.72 & 0.60 & 0.58 \\
$\rho$ & 0.90 & 0.79 & 0.81 \\
$k_{e}, \mathrm{~cm} . \mathrm{sec}^{-1}$ & 0.30 & 0.20 & 0.16 \\
\hline
\end{tabular}

* V vs. saturated mercurous sulphate half-cell.

irreversible systems is negligible ${ }^{3}$; consequently, $E_{\varepsilon}$ should be the outcome of a reversible process. On this basis, the increasingly more negative reversible potential of the $\mathrm{Bi}$ (III) system with increasing chloride concentration is presumably due to the progressive formation of complex chloro-bismuth ions, whose difficulty of reduction increases with increasing number of ligands other than water; the d.c. polarographic wave, which is irreversible in the absence of chloride, approaches reversibility in its presence, probably due to a readier path for the reduction through a chloride "bridge".

\section{Log plots}

The observed slope of the plot of $\log \left[\left(i_{d}-i\right) / i\right]$ vs. $E$ at $25^{\circ}$ for the $\mathrm{Bi}(\mathrm{III})$ reduction, which is $40 \mathrm{mV}$ in the absence of chloride, decreases from 23 to $20 \mathrm{mV}$ with increasing chloride concentration. On the basis of the slope being $59 \cdot 1 / n \mathrm{mV}$, it is theoretically 
TAale 3.-SOLUTION COMPOSTTIONS, CORRESPONDINo CAPILlARY CHARACTERISTICS AND DIFFuston COEFFICIENTS

\begin{tabular}{|c|c|c|c|c|c|c|c|c|c|c|c|c|}
\hline \multirow{2}{*}{$\begin{array}{l}\text { Test } \\
\text { soln. }\end{array}$} & \multicolumn{2}{|c|}{$\begin{array}{l}\text { Solution } \\
\text { com- } \\
\text { position* }\end{array}$} & \multicolumn{2}{|c|}{$\begin{array}{c}\text { Characteristics } \\
\text { of D.M.E. } \\
\text { used }\end{array}$} & \multicolumn{7}{|c|}{$\begin{array}{l}\text { Nature of species present in solution } \\
\text { percentage of Bi(III) present as }\end{array}$} & \multirow{2}{*}{$\begin{array}{c}\text { Bismuth } \\
\text { diffusion } \\
\text { coeff. } D_{\mathrm{n}} \\
\left(10^{8} \mathrm{~cm}^{2} \mathrm{sec}^{-1}\right)\end{array}$} \\
\hline & $\begin{array}{r}\text { Total } \\
\text { Bi(III) } \\
(\mathrm{mM})\end{array}$ & $\underset{(\mathrm{mM})}{\text { Total }}$ & $\begin{array}{c}t \\
(\sec )\end{array}$ & $\stackrel{m}{(\mathrm{mg} \mathrm{sec}-1)}$ & $\begin{array}{c}\text { Free } \dagger \\
\mathrm{Cl}^{-} \\
(\mathbf{m M})\end{array}$ & $\begin{array}{c}\mathrm{Bi}^{\mathbf{3}+} \\
(\mathrm{mM})\end{array}$ & $\begin{array}{c}\mathrm{BiCl}^{2+} \\
(\mathrm{mM})\end{array}$ & $\mid \begin{array}{l}\mathrm{BiCl}_{2}^{+} \\
(\mathrm{mM})\end{array}$ & $\begin{array}{l}\mathrm{BiCl}_{3} \\
(\mathrm{mM})\end{array}$ & $\begin{array}{l}\mathrm{BiCl}_{4}- \\
(\mathrm{mM})\end{array}$ & $\left|\begin{array}{c}\mathrm{BiCl}_{5}- \\
(\mathrm{mM})\end{array}\right|$ & \\
\hline $\begin{array}{l}\mathbf{a} \\
\mathbf{b} \\
\mathbf{c} \\
\mathbf{d} \\
\mathbf{e} \\
\mathbf{f} \\
\mathbf{g} \\
\mathbf{h} \\
\mathbf{i} \\
\mathbf{j} \\
\mathbf{k}\end{array}$ & $\begin{array}{l}0.253 \\
0.253 \\
0.253 \\
0.253 \\
0.253 \\
0.125 \\
0.51 \\
0.92 \\
0.25 \\
0.25 \\
0.25\end{array}$ & $\begin{array}{c}2.2 \\
6.2 \\
18 \\
60 \\
180 \\
300 \\
300 \\
300 \\
0.0 \\
180 \\
180\end{array}$ & $\begin{array}{l}6 \cdot 9 \\
7 \cdot 0 \\
7 \cdot 5 \\
8 \cdot 1 \\
8 \cdot 9 \\
7 \cdot 6 \\
7 \cdot 0 \\
6.9 \\
9 \cdot 0 \\
8 \cdot 3 \\
9 \cdot 2\end{array}$ & $\begin{array}{l}0.69 \\
0.65 \\
0.61 \\
0.59 \\
0.65 \\
0.69 \\
0.72 \\
0.72 \\
0.86 \\
0.81 \\
0.75\end{array}$ & $\begin{array}{c}1 \cdot 87 \\
5 \cdot 75 \\
17 \cdot 8 \\
60 \\
180 \\
300 \\
300 \\
300 \\
0.0 \\
180 \\
180\end{array}$ & $\begin{array}{r}42 \\
9 \\
1\end{array}$ & $\begin{array}{r}21 \\
13 \\
4 \\
1\end{array}$ & $\begin{array}{r}35 \\
70 \\
69 \\
40 \\
13 \\
6 \\
6 \\
6 \\
\\
13 \\
13\end{array}$ & $\begin{array}{r}2 \\
8 \\
25 \\
48 \\
47 \\
34 \\
34 \\
34 \\
\\
47 \\
47\end{array}$ & $\begin{array}{r}1 \\
9 \\
26 \\
32 \\
32 \\
32 \\
\\
26 \\
26\end{array}$ & $\begin{array}{r}2 \\
14 \\
28 \\
28 \\
28 \\
\\
14 \\
14\end{array}$ & $\begin{array}{l}0.93 \\
0.93 \\
0.98 \\
0.93 \\
0.93 \\
1.12 \\
0.84 \\
0.78 \\
1.53 \\
0.93 \\
0.93\end{array}$ \\
\hline
\end{tabular}

* The solution was also $0.5 \mathrm{M}$ in $\mathrm{HClO}_{4}$.

$\dagger$ Calculated as the difference between total $\mathrm{Cl}^{-}$added and $\mathrm{Cl}^{-}$bound in complex ions.

Table 4.-EFfect of $\left[\mathrm{Cl}^{-}\right]$on POLAROGRaphic and POTENTIOMETRIC RESULTS FOR Bi(III)

\begin{tabular}{|c|c|c|c|}
\hline \multirow{2}{*}{$\begin{array}{l}{\left[\mathrm{Cl}^{-}\right]} \\
(\mathrm{mM})\end{array}$} & \multicolumn{2}{|c|}{$\mathrm{Bi}(\mathrm{III})$ at $\mathrm{DME}^{*}$} & \multirow{2}{*}{$\frac{\mathrm{Bi}(\mathrm{III}) / \mathrm{Bi}(\mathrm{Hg}) \dagger}{\begin{array}{c}-E_{\mu} \\
(\mathrm{mV})\end{array}}$} \\
\hline & $\begin{array}{l}-E_{s} \\
(\mathrm{mV})\end{array}$ & $\begin{array}{l}-E_{1 / 8} \\
(\mathrm{mV})\end{array}$ & \\
\hline 18 & ${ }^{430}$ & ${ }^{415}$ & $\begin{array}{c}<20[20 \mathrm{mM}] \\
>17\end{array}$ \\
\hline 60 & ${ }_{40}^{453}$ & ${ }_{30}^{444}$ & ca. 37 \\
\hline 180 & ${ }_{15}^{493}$ & $\begin{array}{l}474 \\
14\end{array}$ & $\begin{array}{ll}69 & \\
& 18\end{array}$ \\
\hline 300 & 508 & 488 & 87 \\
\hline
\end{tabular}

* $0.25 \mathrm{mM}$ Bi(III) in $0.5 \mathrm{M} \mathrm{HClO}_{4}$ (present study).

$\dagger 0.50 \mathrm{mM} \mathrm{Bi}(\mathrm{III})$ in $1.0 \mathrm{M} \mathrm{HClO}_{4}$ (Ahrland and Grenthe).

$19.7 \mathrm{mV}$ if 3 electrons are involved; if the activation step involves 1 or 2 electrons, the slope, according to some authors, would correspondingly be 59.1 or $29.6 \mathrm{mV}$. The interpretation of the slope of the log plot on the basis that the latter equals $\left(59 / \alpha n_{a}\right) \mathrm{mV}$, where $n_{a}$ equals the number of electrons involved in the activation step, seems unreasonable since the data would then indicate a value of $\alpha$ near unity and an $n_{a}$ value of 3 . The decrease in slope may be taken to indicate that the polarographic reduction becomes more reversible with increasing chloride concentration. In any event, the $\log$ plot is not a sufficiently accurate measure of reversibility; in fact, the 
present results demonstrate how insensitive this plot is in cases where the observed values are at all close to an expected reversible value. Where other parameters conclusively show a progressive change in reversibility with changing chloride concentration, the log plot slope changes only $3 \mathrm{mV}$, a barely significant difference in view of the usual inaccuracies of plotting, i.e. values differing by 5 or even $10 \mathrm{mV}$ from expected values have been assumed to substantiate, e.g., a one-electron reversible process.

\section{Heterogeneous rate constant}

The rate constant for the heterogeneous electrode reaction increases with increasing chloride concentration at constant bismuth concentration and with decreasing bismuth concentration at constant chloride concentration. On the basis of Delahay's criterion ${ }^{4}$ that reversible d.c. polarographic waves can be observed for values of $k_{\circ}$ greater than ca. $2 \times 10^{-2} \mathrm{~cm} \mathrm{sec}^{-1}$, the reduction of $\mathrm{Bi}$ (III) becomes increasingly reversible as the $\left[\mathrm{Cl}^{-}\right] /[\mathrm{Bi}(\mathrm{III})]$ ratio increases. However, this ratio is not the sole determining factor; the results do not show a smooth progression of $k_{e}, \rho$ and $\alpha$ (Table 5), indicating that the absolute bismuth and chloride concentrations also have an effect.

For comparison with the present data, Randles and Somerton ${ }^{5}$ reported values of $k_{e}$ for $\mathrm{Bi}(\mathrm{III})$ of greater than 1 in $1 \mathrm{M}$ hydrochloric acid and of $3 \times 10^{-4} \mathrm{~cm} \mathrm{sec}^{-1}$ in $1 \mathrm{M}$ perchloric acid; $k_{\mathrm{B}}$ in $1 \mathrm{M} \mathrm{HClO}_{4}$ increases on addition of small (up to $0.05 \mathrm{M}$ ) amounts of chloride ion. The $\mathrm{Bi}(\mathrm{III})$ concentration was given as roughly $10^{-3} \mathrm{M}$ in that work, and approximately the same concentration of $\mathrm{Bi}$ amalgam was used for the dropping electrode. Even on the basis of the different experimental conditions the lack of agreement in $k_{e}$ values is disturbing; it indicates that different methods of determining $k_{e}$ can lead to widely differing results, e.g. the wide variation in $k_{\theta}$ reported for the reduction of Cd(II) (Table 6). Moreover, measurement of $k_{\varepsilon}$ on the same system by two different methods (d.c. polarization curves and bridge measurements of electrode impedance) in the course of a single study ${ }^{6}$ led to values differing by a factor of $10^{3}$. Possible reasons for such differences indicate the need for further investigation. In the meantime, one must remember this uncertainty in reported $k_{e}$ values.* In the present study, the authors seek only to discuss the possible relevance of $k_{e}$, as determined by a.c. polarography, in relation to other parameters.

\section{A.C. efficiency}

The theoretical magnitude of the faradaic alternating current, expected when an alternating potential of a few $\mathrm{mV}$ amplitude is superimposed on a d.c. polarizing potential (conditions of a.c. polarography), can be calculated. ${ }^{8}$ The most useful parameter for this purpose is $J$, which is a function of the alternating current and, being independent of the frequency and amplitude of the alternating potential, a characteristic of the process. The resulting a.c. polarographic criterion of reversibility is based on the ratio of the experimental and calculated values of $J$, which is defined as the a.c. efficiency, $\rho$. The latter should have values between 0 and 1 , corresponding to totally irreversible and reversible systems respectively.

In the case of $\mathrm{Bi}(\mathrm{III}), \rho$ increases with increasing chloride concentration at constant bismuth concentration, reaching unity within experimental error. These increases

\footnotetext{
* Delahay and Trachtenberg have recently pointed out ${ }^{7}$ that one of the favourite techniques used in $k_{e}$ measurement-the hanging drop method--gives erroneously low results.
} 
TABle 5.-Electrode Parameters as a Function of tHe Ratio of [Cl]/[Bi]

\begin{tabular}{r|l|l|l|l|l|l}
\hline$\frac{[\mathrm{Cl}]}{[\mathrm{Bi}]}$ & $\begin{array}{c}\text { Log } \\
\text { slope } \\
(\mathrm{mV})\end{array}$ & $\alpha$ & $\begin{array}{c}k_{s} \\
\left(\mathrm{~cm} \mathrm{sec}^{-1}\right)\end{array}$ & $\rho$ & $\begin{array}{c}E_{1 / 2} \\
(-\mathrm{V})\end{array}$ & $\begin{array}{c}E_{s} \\
(-\mathrm{V})\end{array}$ \\
\hline & & & & & \\
\hline $9 \dagger$ & 40 & & 0.023 & 0.06 & $0.441^{*}$ & 0.401 \\
$25 \dagger$ & 23 & 0.46 & 0.030 & 0.20 & 0.410 & 0.410 \\
$71 \dagger$ & 23 & 0.46 & 0.079 & 0.38 & 0.413 & 0.410 \\
$237 \dagger$ & 23 & 0.54 & 0.21 & 0.64 & 0.415 & 0.430 \\
$325_{\ddagger}^{+}$ & 20 & $0.67^{*}$ & 0.20 & $1.06^{*}$ & 0.444 & 0.453 \\
$590_{\ddagger}^{+}$ & 19 & 0.58 & $0.16^{*}$ & 0.81 & 0.490 & 0.506 \\
$710 \dagger$ & 20 & 0.69 & 0.20 & 0.79 & 0.490 & 0.508 \\
$2400_{\ddagger}^{+}$ & 20 & 0.72 & 0.20 & 0.98 & $0.474^{*}$ & $0.493^{*}$ \\
& & & 0.30 & 0.90 & 0.487 & 0.511 \\
\hline
\end{tabular}

* Values significantly not fitting into the general progression.

$\dagger \mathrm{Bi}(\mathrm{III})$ concentration $=0.253 \times 10^{-3} \mathrm{M} ; \mathrm{Cl}^{-}$concentration varies from 0.0 to $0 \cdot 18 \mathrm{M}$.

$\ddagger \mathrm{Bi}(\mathrm{III})$ concentration $=(0.92,0.51,0.125) \times 10^{-3} \mathrm{M} ; \mathrm{Cl}^{-}$concentration $=0.3 \mathrm{M}$.

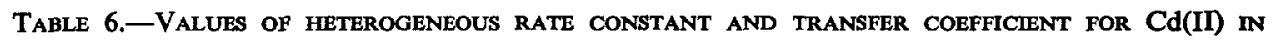
VARIOUS MEDIA USING VARIOUS METHODS OF MEASUREMENT

\begin{tabular}{|c|c|c|c|c|c|}
\hline Method & Medium & Electrode & $k_{0}$ & $\alpha$ & Reference \\
\hline $\begin{array}{l}\text { Radiofrequency } \\
\text { Current-Step } \\
\text { A.C. electrolysis } \\
\text { Voltage-Step } \\
\text { A.C. polarography } \\
\text { Modified bridge } \\
\text { Radiofrequency } \\
\text { Radiofrequency } \\
\text { Radiofrequency } \\
\text { A.C. polarography } \\
\text { A.C. polarography }\end{array}$ & $\begin{array}{c}0.5 \mathrm{M} \mathrm{K}_{2} \mathrm{SO}_{4} \\
0.5 \mathrm{M} \mathrm{Na}_{2} \mathrm{SO}_{4} \\
0.5 \mathrm{M} \mathrm{Na}_{2} \mathrm{SO}_{4} \\
1.0 \mathrm{M} \mathrm{Na}_{2} \mathrm{SO}_{4} \\
0.1-1 \mathrm{M} \mathrm{Na}_{2} \mathrm{SO}_{4} \\
1 \mathrm{M} \mathrm{KO}_{3} \\
1 \mathrm{M} \mathrm{KNO}_{3} \\
1 \mathrm{M} \mathrm{NaClO}_{4} \\
1 \mathrm{M} \mathrm{KCl} \\
0.1-1 \mathrm{M} \mathrm{KCl} \\
0.5 \mathrm{M} \mathrm{HCl}\end{array}$ & $\begin{array}{c}\mathbf{H g} \\
\mathrm{Cd}(\mathrm{Hg}) \\
\mathrm{Cd}(\mathbf{H g}) \\
\mathrm{Cd}(\mathbf{H g}) \\
\mathbf{H g} \\
\mathrm{Cd}(\mathbf{H g}) \\
\mathbf{H g} \\
\mathbf{H g} \\
\mathbf{H g} \\
\mathbf{H g} \\
\mathbf{H g}\end{array}$ & $\begin{array}{l}0.08 \\
0.026 \\
0.042 \\
0.045 \\
0.6 \\
6 \cdot 3 \\
2 \cdot 3 \\
2 \cdot 9 \\
0 \cdot 17\end{array}$ & $\begin{array}{l}0.08 \\
0.25 \\
0.17 \\
0.22 \\
0.37\end{array}$ & $\begin{array}{r}10 \\
11 \\
12 \\
13 \\
8 \\
5 \\
10 \\
10 \\
10 \\
8 \\
8\end{array}$ \\
\hline
\end{tabular}

parallel those in $k_{e}$. The a.c. efficiency of a process may be a measure of the thermodynamic reversibility of the process; entropic energy losses due to thermodynamic irreversibility would correspond to the loss, as heat, of part of the electrical energy supplied by the alternating potential, only part remaining in the form of electrical energy as the observable alternating current.

\section{Transfer coefficient}

The transfer coefficient, $\alpha$, varies from 0.46 to 0.72 with increasing chloride concentration. Determination of $\alpha$ in the absence of chloride was not possible, the faradaic alternating current being too small at the lowest frequencies which could be used in conjunction with the present frequency filter. ${ }^{8}$ 
The assumption made on occasion, ${ }^{9}$ that in a reversible process $\alpha$ equals 0.5 , does not hold true in the present case; at the highest chloride concentrations, where the reaction is closest to reversible as judged by $k_{s}$ and $\rho, \alpha$ is further from 0.5 than at the low chloride concentrations where the reaction is less reversible.

On the basis of the original definition of $\alpha$ as the fraction of the potential drop across the interface, which facilitates the cathodic reaction, $\alpha$ would be expected to depend on the structure of the electrical double layer, specifically, on the manner in which the potential in the interphase varies with distance from the electrode surface and on the interatomic and interionic distances involved in the electron transfer step. The transfer coefficient can then be mathematically related to the reversibility of the system only if the reversibility can also be expressed in terms of the distances and potential variations involved.

\section{CONCLUSIONS}

Consideration of the d.c. polarographic results, taken by themselves, do not permit an unequivocal interpretation of the changes which occur in the bismuth system on increasing the chloride concentration. The shift in $E_{1 / 2}$ may be due to changes in reversibility or merely to changes in the reversible potential of the system with changing complexation. The change in log-plot slope is insufficiently sensitive to indicate reliably possible reversibility changes. Consideration of the results obtained both by d.c. and a.c. polarography indicate that the negative shift in $E_{1 / 2}$ is due to changes in complexation, and that this shift is accompanied by an increase in the reversibility of the system.

The behaviour of the bismuth system supports the conclusion that the various parameters used in the literature to report the reversibility of a system under polarographic conditions do not all measure the same aspect of that system. The use of more precise terminology is quite evidently desirable. Such terminology should distinguish clearly whether a system may be regarded as thermodynamically reversible, or whether it merely behaves in the same way as a theoretically proposed ("ideal", "reversible", etc.) model when studied by one technique or another. Attempts to classify processes as reversible or irreversible (meaning thermodynamically reversible or irreversible, in the currently accepted usage) on the basis of polarographic studies must be made cautiously and with due regard to the experimental and theoretical limitations involved. All too often, such classifications have been made with insufficiently reliable experimental data or by intuitively invoking a correlation between thermodynamic reversibility and some other quantity without the foundation of a theoretically derived treatment.

\section{Apparatus}

\section{EXPERIMENTAL}

The apparatus used has been previously described ${ }^{8}$ with the following exceptions: for reasons not connected with the functioning of the apparatus, the previously used Hewlett-Packard Model 712A power supply was replaced by a Model $712 \mathrm{~B}$; to prevent contamination of the test solution by chloride ion, a saturated mercurous sulphate half-cell was used as reference electrode. The low-resistance capillaries used for the dropping mercury electrode were again not stable over long periods of time and showed an induction period; $m$ and $t$, however, remained constant within 1 or 2 per cent during the duration of each experiment, i.e. the measurement of one solution composition over the frequency range; the relevant values are given in Table 3 . 


\section{Procedures}

The test solutions were all $0.5 \mathrm{M}$ with respect to perchloric acid; theircompositions with respect to bismuth and chloride are shown in Table 3 . Test solutions (a) to (h) were prepared by dissolving reagent grade bismuth oxychloride in perchloric acid and adding the requisite amount of chloride in the form of hydrochloric acid solution, taking into account the chloride present in the bismuth oxychloride. Solutions (i) to $(k)$ were prepared by dissolving reagent grade bismuth subcarbonate in perchloric acid, or previously prepared perchloric-acid-hydrochloric-acid solution.

D.C. polarographic values were determined from manually recorded polarograms, using a potentiometer-galvanometer arrangement. Other measurements were made using previously described procedures. ${ }^{8}$ In determination of the heterogeneous rate constant, an amplitude of $6.2 \mathrm{mV}$ r.m.s. between the D.M.E. and the pool anode was used. In the determination of $\alpha$, the amplitude was in the range of $2-10 \mathrm{mV}$ r.m.s.; changes of amplitude in this range have no effect on the observed results. The temperature was $25^{\circ} \pm 1^{\circ} \mathrm{C}$. Oxygen was removed from the test solutions by purging with purified nitrogen.

\section{Determination of diffusion coefficients}

In order to determine the transfer coefficient (equations 2, 3 and 4 in reference $8 b$ ) and to calculate the theoretical value of $J$ (equation 24 in reference $8 \mathrm{a}$ ), it is necessary to know the diffusion coefficients of the oxidized and reduced species. $D_{0}$ for $\mathrm{Bi}$ (III) seems to vary greatly depending on the background electrolyte, e.g. $0.41 \times 10^{-5} \mathrm{~cm}^{2}$ $\sec ^{-1}$ in $M$ tartaric acid, $0.60 \times 10^{-5}$ in $M$ perchloric acid and $0.87 \times 10^{-5}$ in $M$ potassium chloride plus $0 \cdot 1 \mathrm{M}$ hydrochloric acid. ${ }^{11}$ Consequently, $D_{0}$ was determined for the solutions used in the present study by calculation from the simple form of the Ilkovic equation, using d.c. polarograms of each of the solutions investigated. $D_{R}$ was taken as $0.99 \times 10^{-5} \mathrm{~cm}^{2} \mathrm{sec}^{-1} .^{12}$

Acknowledgement-The authors would like to thank the Atomic Energy Commission and Horace H. Rackham Graduate School of the University of Michigan which helped to support the work described.

\section{REFERENCES}

1. L. Newman and D. N. Hume, J. Amer. Chem. Soc. 79, 4576 (1957).

2. S. Airrland and I. Grenthe, Acta Chem. Scand. 11, 1111 (1957).

3. P. Delahay, New Instrumental Methods in Electrochemistry, pp. 174-5. Interscience, New York (1954).

4. P. Delahay, J. Amer. Chem. Soc. 75, 1430 (1953).

5. J. E. B. RANDLES and K. W. Somerton, Trans. Faraday Soc. 48, 951 (1952).

6. H. A. LAITINEN and H. C. GAUR, J. Electrochem. Soc. 104, 730 (1957); 105, 433 (1958).

7. P. Delahay and I. Trachtengerg, J. Amer. Chem. Soc. 80, 2094 (1958).

8. (a) H. H. Bauer and P. J. Elving, Anal. Chem. 30, 334 (1958); (b) Ibid. 341.

9. J. van CaKenderghe, Bull. Soc. Chim. Belge 60, 3 (1951).

10. G. C. Barker, Anal. Chim. Acta 18, 118 (1958).

11. W. Vielstich and P. Delahay, J. Amer. Chem. Soc. 79, 1874 (1957).

12. H. Gerischer, $Z$. Elektrochem. 57, 604 (1953).

13. T. Berzins and P. Delahay, J. Amer. Chem. Soc. 77, 6448 (1955).

14. T. Pavlopoulos and J. D. M. Strickland, J. Electrochem. Soc. 104, 117 (1957).

15. W. C. Cooper and N. H. Furman, J. Amer. Chem. Soc. 74, 6183 (1953). 